\title{
Unemployment forecasts, time varying coefficient models and the Okun's law in Spanish regions
}

\author{
Miquel Clar-Lopez • Jordi López-Tamayo • Raul Ramos*
}

AQR-IREA, Universitat de Barcelona, Spain

Received: 10 September 2014

Revised: 10 December 2014

Accepted: 11 December 2014

\begin{abstract}
During the Great Recession, output and unemployment responses have differed markedly across Spanish regions. Our objective is to evaluate the relative accuracy of forecasting models based on the Okun's law compared to alternative approaches. In particular, we want to analyse if a time varying coefficient specification of the Okun's law provide better forecasts than alternative models in two different periods: a first period from 2002 to 2007 characterized by sustained economic growth in all provinces, and a second period from 2008 to 2013 characterized by the impact of the Great Recession. The obtained results allow us to conclude that, in general, the use of these models improve the forecasting capacity in most regions, but do not provide reliable forecast.
\end{abstract}

Keywords: unemployment forecasts, Okun's law, time-varying coefficient models, regional labor markets

JEL Classification Codes: C53, R23, J64

\section{Introduction}

During the last decades, the Spanish labour market has been characterised by high unemployment rates, particularly when compared to other European Union countries. Moreover, the low interregional geographical mobility together with the peculiarities of the collective bargaining systems until the last reforms have amplified the differences in unemployment rates from a regional perspective (López Bazo et al., 2005).

More recently, the financial crisis, the burst of the housing bubble and the dramatic fall of employment in the construction sector during the Great Recession has magnified the problem. Given its social and political significance, forecasting unemployment rates is particularly important to help policy makers in their decision-making. As a result, the literature dealing with unemployment rate forecasting is consequently large: see, for instance, Funke (1992),

\footnotetext{
*Corresponding author. E-mail: rramos@ub.edu.
}

Citation: Clar-Lopez, M., J. Lopez-Tamayo and R. Ramos (2014) Unemployment forecasts, time varying coefficient models and the Okun's law in Spanish regions, Economics and Business Letters, 3(4), $247-262$. 
Rothman (1998), Elliot and Timmerman (2008) or, more recently, Franses et al. (2014). The literature has also recently rediscovered (see Knoteck, 2007; Ball et al., 2015 or Guisinger and Sinclair, 2015) the possibility of using the Okun's law as a simple but potentially powerful forecasting model. Using 1950's data for the US economy, Okun (1962) found an empirical negative relationship between changes in the unemployment rate and output growth. This relationship has been estimated and tested for several countries (see for instance Huang and Yen, 2013), but also for regions: Freeman (2000) and Pereira (2014) for the United States, Adanu (2005) for Canadian regions; Durech et al. (2014) for regions in the Czech Republic and Slovakia; Kangarsharju et al. (2012) for the Finnish regions; Christopoulos (2004), Karfakis et al. (2014), and Apergis and Rezitis (2014) for Greek regions; MarieEstelle and Facchini (2013) for French regions and, for the Spanish regions, it is worth mentioning the research by Villaverde and Maza (2007 and 2009), Ballesteros et al. (2012), Martín-Román and Sylvina-Porras (2012). However, none of these studies are focused on regional forecasting but on the explanatory capacity of models based on the Okun's law.

The objective of this paper is to evaluate the relative accuracy of forecasting models based on the Okun's law compared to alternative approaches in the particular context of Spanish regions. We want to analyse if the use of time varying coefficient models improves the forecasting accuracy of the Okun's law when compared to fixed coefficient models in two different periods: a first period from 2002 to 2007 characterized by sustained economic growth in all provinces, and a second period from 2008 to 2013 characterized by the impact of the Great Recession. The use of time varying coefficient models in the context of unemployment forecasting has been scarce and, to our knowledge, inexistent at the regional level. In particular, Franses et al. (2004) consider time series univariate models with timevariation in the AR parameters and apply them to obtain unemployment forecasts for the US, Canada and Germany. Their results show that this model outperforms alternative models in terms of forecasting accuracy.

\section{Methods}

The Okun's law is given by the following expression:

$$
\Delta U R_{t}=\alpha+\beta \cdot \Delta G D P_{t}+\varepsilon_{t},
$$

where $\Delta U R_{t}$ and $\Delta G D P_{t}$ denote, respectively, changes in the unemployment rate from $t-1$ to $t$ (or differences in logs) and output growth (usually measured by changes from $t-1$ to $t$ in the logarithm of Gross Domestic Product - GDP); $\alpha$ is an intercept; $\beta$, usually known as Okun's coefficient, explains how changes in the logarithm of output affect variations in the unemployment rate; and, $\varepsilon_{t}$ denotes a random term. The ratio $-\frac{\alpha}{\beta}$ provides an estimate of the required output growth to stabilize the unemployment rate. The basic specification shown in Eq. (1) can also be augmented by the inclusion of lags of output and unemployment in order to take into account the possibility that the relationship between the two variables could not only be contemporaneous but a dynamic one.

An alternative version of the Okun's law relates the unemployment rate to the output gap (i.e., the difference between actual output and potential output - $G D P_{t}^{*}$ ). This alternative version of the law is given as follows:

$$
U R_{t}=\alpha+\beta \cdot\left(G D P_{t}-G D P_{t}^{*}\right)+\varepsilon_{t},
$$


where the intercept $\alpha$ can be interpreted as the unemployment rate in the case of full employment. Eq. 2 can be reformulated as:

$$
U R_{t}-U R_{t}^{*}=\beta \cdot\left(G D P_{t}-G D P_{t}^{*}\right)+\varepsilon_{t},
$$

where $U R_{t}^{*}$ is the natural unemployment rate, and, so $U R_{t}-U R_{t}^{*}$ is the unemployment gap. Although probably the relationship captured by Eq. 3 is more meaningful than Eq. 1 from an economic point of view, the main problem is that potential output and the natural unemployment rate are not observable, so it is necessary to estimate them using filtering methods such as the Hodrick-Prescott or pass-band filters ${ }^{1}$ before Eq. 3 can be empirically analysed. For this reason, and taking into account that the objective of this paper is to analyse Okun's law forecasting accuracy, we will use Eq. 1 instead of Eq. 3.

The strategy to test if the Okun's law can provide useful information to improve forecasts of regional unemployment rate in Spain has been the following. Four different sets of models have been considered (naïve, auto-regressive, fixed coefficient models and time varying coefficient models) to obtain forecasts for the unemployment rate of the different Spanish provinces and the Mean Absolute Percentual Error (MAPE) has been computed for different forecast horizons. The comparison of the MAPE values for the models not based in the Okun's law with those derived from it would permit to assess whether it is useful or not to improve unemployment forecasts.

\section{Nä̈ve methods}

As usual in the literature, the naïve method considers that the value of the variable of interest in a particular period does not change from the last valid observation:

$$
U R_{t}=U R_{t-1} .
$$

A slightly different version of this approach assumes that changes in the variable are the same to the ones observed in the previous period:

$$
U R_{t}=U R_{t-1} \cdot \Delta U R_{t-2} .
$$

\section{Autoregressive models}

The widely known autoregressive model (also known as distributed-lags model) explains the behaviour of the endogenous variable as a linear combination of its own past values:

$$
U R_{t}=\phi_{1} U R_{t-1}+\phi_{2} U R_{t-2}+\ldots+\phi_{p} U R_{t-p}+\varepsilon_{t} .
$$

The key question is how to determine the number of lags that should be included in the model. We have considered different models with a minimum number of 1 lag up to a maximum of 3, selecting that model with the lowest value of the Akaike Information Criteria (AIC). In order to check the robustness of the results to different selection criteria, we have also considered the Schwartz criteria yielding exactly the same results.

\section{Fixed and time varying coefficient models}

Ordinary Least Squares (OLS) estimation of Eq. (1) allows to obtain forecasts for the unemployment rate. Eq. (1) can also be augmented with lags of GDP but also unemployment in order to take into account the dynamic response of unemployment to GDP shocks but also

\footnotetext{
${ }^{1}$ Moreover, there is no consensus in the literature on which of the different procedures is more appropriate to estimate the unobservable variables.
} 
to control for the persistence of regional unemployment (hysteresis). In order to distinguish both sets of forecasts, we denote forecasts from Eq. (1) as "static Okun's law" while forecasts from the augmented Eq. (1) is denoted as "dynamic Okun's law".

However, as previously mentioned in the presence of structural instability, estimates of $\alpha$ and $\beta$ will not be appropriate and lead to misleadings forecasts. For this reason, we also consider a time varying coefficient specification of the Okun's law. For simplicity, we only consider the time varying coefficient specification of the static version of the Okun's law. Time varying coefficient models try to consider in the specification and estimation of the model the instability in the relationship between the endogenous and the exogenous variables. This instability can be caused by structural changes but also by specification errors ((Dzciechciarz, 1989; Engle and Watson, 1987; Min and Zellner, 1993). Time varying coefficient models are usually formed by two equations: a first equation that captures the time evolution of the considered coefficients denoted by $\beta_{t}$ :

$$
\beta_{t}=\phi_{t} \cdot \beta_{t-1}+W_{t} \cdot \theta_{t}+\eta_{t},
$$

and where $\phi_{t}$ represents the magnitude of the change in the coefficient in each time period, $W_{t}$ denotes potential explanatory variables of the value of $\beta_{t}, \theta_{t}$ are the coefficients associated to these variables and $\eta_{t}$ is a random error term that is assumed to follow a normal distribution with zero mean and variance $\sigma_{\eta}^{2}$. The second equation is related to the equation of interest, in our case, the Okun's law, with $Y_{t}$ denoting the endogenous variable, $X_{t}$ the explanatory variables with time varying coefficients and $Z_{t}$ other explanatory variables with non-time varying coefficients, denoted by $\gamma$ :

$$
Y_{t}=X_{t} \cdot \beta_{t}+Z_{t} \cdot \gamma+\varepsilon_{t},
$$

$\mathcal{E}_{t}$ is a random error term following a normal distribution with zero mean and variance $\sigma_{\varepsilon}^{2}$.

Taking into account the previous literature and the arguments provided by Engle and Watson (1987) this general specification model is usually simplified for empirical work assuming that $\phi_{t}=1$ and $\theta_{t}=0$. This restricted specification is known as systematically varying coefficient models and, in this case, coefficients are assumed to behave as a random walk (Shively and Kohn, 1997). The system formed by the restricted specification of Eq. 6 and Eq. 7 can be transformed into a state-space model where the first is the state equation and the second is the measurement equation. In the particular case of the Okun's law the model to estimate would be the following one:

$$
\begin{gathered}
U R_{t}-U R_{t-1}=\alpha_{t}+\Delta G D P_{t} \cdot \beta_{t}+\varepsilon_{t}, \\
\alpha_{t}=\alpha_{t-1}+\eta_{t}, \\
\beta_{t}=\beta_{t-1}+\zeta_{t} .
\end{gathered}
$$

The estimation of this model can be done using the Kalman filter, once the values of the hyperparameters of the model (variance of the random terms of the three equations) are estimated by maximum likelihood and the OLS estimates of the Okun's law are used as initial values.

\section{Data}

In order to carry out our analysis, we have used information for the 17 Spanish Autonomous Communities (NUTS-II level regions). Data for unemployment rates comes from the Spanish Labour Force Survey (LFS) provided by the National Institute of Statistics (INE) while data 
for real output growth comes from the Spanish Regional Accounts (SRA). Although unemployment rates data are available at the quarterly frequency, regional output is only available at the annual frequency. In both cases, data is available since 1980 up to 2013.

\section{Results}

Before moving to the analysis of the forecast competition, figure 1 shows the evolution of changes in unemployment and GDP growth for the Spanish economy for the considered period. As we can see from figure 1, it is not straightforward to conclude that the first difference of both series behave as stationary time series. This is a relevant point as this is a requirement of the Okun's law specification used to derive the different time series models used for the forecasting competition. Detailed results of the analysis of the time series properties of unemployment and GDP for Spain and the 17 Spanish Autonomous Communities using the Augmented Dickey Fuller test, Phillips and Perron test, ElliotRothenberg-Stock test, Schmidt-Phillips test, Kwiatkowski-Phillips-Schmidt-Shin test, ZivotAndrews test and the Clemente-Montañes and Reyes test are available from the authors on request. Due to space limitations, we only show the results of the Augmented Dickey-Fuller test in table 1.

Results from table 1 permit us to conclude that, with the only exception of unemployment in the Basque country (País Vasco), in all Autonomous Communities at the usual significance levels we reject the null hypothesis that there is a unit root in the two variables after differentiating. Results from other unit roots or stationary tests are very similar and validate our empirical specification of the Okun's law. However, it is worth mentioning that, as it can be seen in the first panel of table 1, in a few regions like Asturias, Extremadura and La Rioja a different specification could perhaps be more appropriate. However, we prefer to keep a homogenous specification across the considered regions.

Figure 1. Changes in unemployment and GDP growth - Spain 1980- 2013
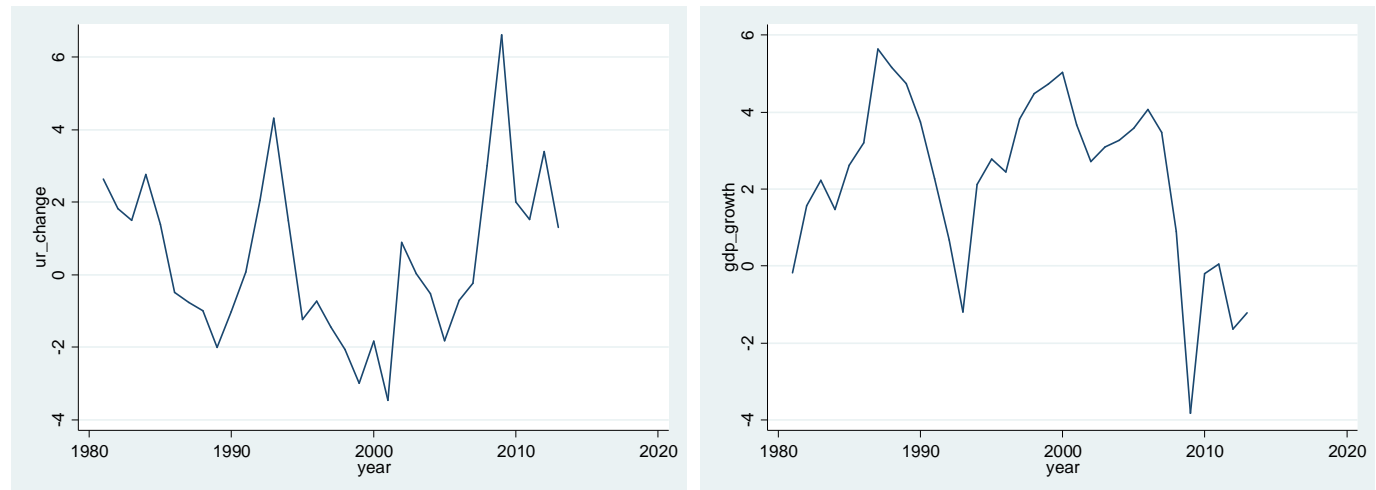

In order to evaluate the relative forecasting accuracy of the models, for each province all models were estimated for two different periods: until 2001 and until 2007. This allows us to consider two different periods to assess the capacity of the model in terms of forecasting: a first period from 2002 to 2007 and a second period from 2008 to 2013. The first corresponds to a period of sustained economic growth in all provinces, while the second one is clearly a recessionary period. For the two periods, models are reestimated in each year and forecasts are computed. Given the availability of actual values, forecast errors for each province and method can be computed in a recursive way (i.e., for the 1 year forecast horizon, 6 forecast 
errors can be computed for each province and period) $)^{2}$. In order to summarise this information, the Mean Absolute Percentage Error (MAPE) ${ }^{3}$ has been computed. Its values provide useful information in order to analyse the forecast accuracy of each method, so methods can be ranked according to their values. For the 2 years forecast horizon, the strategy has been similar. The results of our forecasting competition are shown in tables 2 and 3 . In particular, the average values of the MAPE obtained from recursive forecasts for 1 and 2 yearss ahead for the different models and provinces are shown in these tables. The obtained results permit to conclude that, as expected, forecasts errors increase in the second period when compared to the first one. Regarding the forecast accuracy of the different methods, in most cases the fixed and the time varying coefficient specifications of the Okun's law provide more accurate forecasts than the rest of the methods, being the autoregressive model the one usually displaying the highest MAPE values. However, it is worth mentioning that, for most regions, the accuracy of the models is limited as the MAPE is usually above the 5\% threshold. For instance, the values of the MAPE are clearly above the average in the three regions where the ADF test yielded some doubts about the validity of the specification (Asturias, Extremadura and La Rioja), so it is possible that in some regions forecasting accuracy could be improved if we deviate for the common specification assumed in this paper.

However, one key question that should be addressed is whether the reduction in MAPE when comparing models based and not based in the Okun's law is statistically significant. With this aim, we have calculated the measure of predictive accuracy proposed by Diebold and Mariano (1995) between the two best models based and not based in the Okun's law for the two subperiods and two forecast horizon considered in our analysis. Given these two competing forecasts and the actual series for each quantitative variable, we have calculated the $\mathrm{S}(1)$ measure which compares the mean difference between a loss criteria (in this case, the root of the MAPE) for the two predictions using a long-run estimate of the variance of the difference series. In order to estimate this long run variance from its autocovariance function, we have used the Bartlett kernel, as it guarantees that variance estimates are positive definite, while the maximum lag order has been calculated using the Schwert criterion as a function of the sample size. The results are shown in tables 4 and 5. A negative value of the $S(1)$ statistics indicates that the first method is better than the second while a positive value of $S(1)$ indicates the opposite. As we can see from both tables, the comparison is nearly always carried out between naïve models and fixed coefficient specifications of the Okun's law (static or dynamic) in the first period and between naïve models and time-varying coefficient specifications of the Okun's law in the second period. In general, results do not support the view that forecast accuracy improve when Okun's law models are used. However, the power of the Diebold-Mariano test could be affected by the short number of forecasts that we are comparing. For this reason, the results of the pair-wise comparison of the considered forecasting methods using a panel version of the Diebold-Mariano test as in Bernoth and Pick (2011) are shown in table 6. In particular, the test statistic is calculated as follows:

$$
\overline{\mathrm{S}(1)}=\frac{1}{\sqrt{\mathrm{N}}} \sum_{\mathrm{i}=1}^{\mathrm{N}} \mathrm{S}_{\mathrm{i}}(1) \text {. }
$$

\footnotetext{
${ }^{2}$ As highlighted by the referee, ex-post forecasts are based on actual values of GDP that (although it is not a realistic assumption for real time forecasting) does not affect the validity of our comparison between fixed and time-varying coefficient models. In any case, we recognise that the values for the measures of forecasting accuracy that are calculated across the paper can be understood as lower bounds as the use of regional GDP forecasts will add higher uncertainty to the unemployment forecasts.

3 MAPE $=\frac{1}{T} \sum_{t=1}^{T} \frac{\left|U R_{t}-\hat{U} R_{t}\right|}{U R_{t}} \cdot 100$, where $\hat{U} R_{t}$ is the forecast of the unemployment rate for period $t$ from the

different forecasting techniques. According to the MAPE's value, it is usual in the literature to establish that a value below 3\% indicates an excellent performance, a value between $3 \%$ and $5 \%$ a good performance and a value above $5 \%$ a bad forecasting performance.
} 
Table 1. Results of the Augmented Dickey-Fuller test

\begin{tabular}{|c|c|c|c|c|c|c|c|c|c|c|c|c|c|c|}
\hline \multirow{3}{*}{$\begin{array}{l}\text { Level of the series is I(1) } \\
\text { Region }\end{array}$} & \multicolumn{7}{|c|}{ Unemployment rate } & \multicolumn{7}{|c|}{ Gross Domestic Product } \\
\hline & \multicolumn{4}{|c|}{ Trend and intercept } & \multicolumn{2}{|c|}{ Intercept } & \multirow{2}{*}{$\begin{array}{c}\text { None } \\
\text { test }\end{array}$} & \multirow[b]{2}{*}{ lag } & \multicolumn{3}{|c|}{ Trend and intercept } & \multicolumn{2}{|c|}{ Intercept } & \multirow{2}{*}{$\begin{array}{c}\text { None } \\
\text { test }\end{array}$} \\
\hline & lag & test & trend & int & test & int & & & test & trend & int & test & int & \\
\hline Spain & 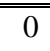 & -2.762 & 2.646 & 3.961 & -2.745 & 3.777 & -2.761 & 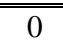 & -2.535 & 2.652 & 3.970 & -2.068 & 2.145 & -1.450 \\
\hline Andalucía & 0 & -2.825 & 2.715 & 4.072 & -2.849 & 4.058 & -2.844 & 0 & -3.266 & 4.074 & 6.111 & -2.662 & 3.544 & -1.838 \\
\hline Aragón & 0 & -3.163 & 3.615 & 5.420 & -3.053 & 4.664 & -3.078 & 0 & -4.154 & 6.353 & 9.525 & -3.372 & 5.692 & -2.129 \\
\hline Asturias, Principado de & 0 & -4.389 & 6.538 & 9.805 & -4.451 & 9.910 & -4.440 & 0 & -4.255 & 6.180 & 9.237 & -3.782 & 7.184 & -2.964 \\
\hline Balears, Illes & 0 & -3.481 & 4.057 & 6.059 & -3.467 & 6.039 & -3.491 & 0 & -4.282 & 6.213 & 9.251 & -2.793 & 3.954 & -1.942 \\
\hline Canarias & 0 & -3.530 & 4.310 & 6.465 & -3.636 & 6.609 & -3.647 & 0 & -3.354 & 3.841 & 5.739 & -3.225 & 5.223 & -2.742 \\
\hline Cantabria & 0 & -3.312 & 3.747 & 5.601 & -3.252 & 5.308 & -3.247 & 0 & -3.591 & 4.381 & 6.567 & -3.360 & 5.649 & -2.476 \\
\hline Castilla - La Mancha & 3 & -3.639 & 4.456 & 6.683 & -3.434 & 5.898 & -3.504 & 0 & -2.757 & 3.025 & 4.537 & -2.337 & 2.732 & -1.606 \\
\hline Castilla y León & 0 & -2.946 & 3.004 & 4.477 & -2.929 & 4.319 & -2.962 & 0 & -2.779 & 2.643 & 3.925 & -2.572 & 3.347 & -2.078 \\
\hline Cataluña & 0 & -3.097 & 3.226 & 4.838 & -3.000 & 4.501 & -2.893 & 0 & -6.263 & 14.656 & 21.914 & -5.039 & 12.749 & -3.110 \\
\hline Comunitat Valenciana & 0 & -3.251 & 3.849 & 5.755 & -3.233 & 5.243 & -3.284 & 0 & -3.597 & 4.754 & 7.114 & -3.353 & 5.639 & -2.441 \\
\hline Extremadura & 0 & -5.049 & 8.500 & 12.749 & -5.121 & 13.112 & -5.087 & 0 & -4.741 & 7.832 & 11.743 & -3.904 & 7.623 & -2.841 \\
\hline Galicia & 0 & -3.204 & 3.451 & 5.175 & -3.263 & 5.325 & -3.157 & 0 & -3.465 & 4.098 & 6.128 & -3.506 & 6.165 & -2.599 \\
\hline Madrid, Comunidad de & 0 & -3.076 & 3.217 & 4.823 & -3.065 & 4.698 & -3.108 & 0 & -2.814 & 2.976 & 4.449 & -2.358 & 2.795 & -1.609 \\
\hline Murcia, Región de & 0 & -3.090 & 3.242 & 4.858 & -3.077 & 4.740 & -3.067 & 0 & -2.879 & 2.930 & 4.376 & -2.810 & 3.967 & -2.150 \\
\hline Navarra, Comunidad Foral de & 0 & -3.048 & 3.209 & 4.812 & -2.881 & 4.152 & -2.914 & 0 & -3.713 & 4.662 & 6.947 & -3.692 & 6.862 & -2.813 \\
\hline País Vasco & 0 & -3.315 & 3.869 & 5.775 & -3.421 & 5.882 & -3.486 & 0 & -2.895 & 2.916 & 4.338 & -2.938 & 4.354 & -2.470 \\
\hline Rioja, La & 4 & -4.403 & 6.794 & 10.132 & -4.236 & 9.030 & -4.339 & 0 & -4.986 & 8.340 & 12.471 & -4.666 & 10.924 & -3.466 \\
\hline
\end{tabular}

Highlighted cells indicate a rejection of the null hypothesis at the 0.05 significance level. 
Table 1. Results of the Augmented Dickey-Fuller test (cont.)

\begin{tabular}{|c|c|c|c|c|c|c|c|c|c|c|c|c|c|c|}
\hline \multirow[t]{3}{*}{ Series' first difference is I(1) } & \multicolumn{7}{|c|}{ Unemployment rate } & \multicolumn{7}{|c|}{ Gross Domestic Product } \\
\hline & \multirow[b]{2}{*}{ lag } & \multicolumn{3}{|c|}{ Trend and intercept } & \multicolumn{2}{|c|}{ Intercept } & \multirow{2}{*}{$\begin{array}{c}\text { None } \\
\text { test }\end{array}$} & \multirow[b]{2}{*}{ lag } & \multicolumn{3}{|c|}{ Trend and intercept } & \multicolumn{2}{|c|}{ Intercept } & \multirow{2}{*}{$\begin{array}{c}\text { None } \\
\text { test }\end{array}$} \\
\hline & & test & trend & int & test & int & & & test & trend & int & test & int & \\
\hline Spain & 2 & -3.519 & 4.138 & 6.194 & -2.080 & 2.219 & 0.117 & 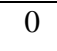 & -5.500 & 10.150 & 15.215 & -1.661 & 19.200 & -5.776 \\
\hline Andalucía & 0 & -6.364 & 13.573 & 20.359 & -1.182 & 1.176 & -6.584 & 0 & -7.044 & 16.790 & 25.125 & -1.742 & 15.574 & -6.183 \\
\hline Aragón & 0 & -6.001 & 12.066 & 18.039 & -0.950 & 0.721 & -6.180 & 0 & -7.180 & 17.790 & 26.519 & -1.844 & 17.263 & -6.753 \\
\hline Asturias, Principado de & 1 & -7.346 & 18.041 & 27.053 & -1.739 & 1.685 & 0.376 & 1 & -7.732 & 19.941 & 29.905 & -1.887 & 4.260 & 2.109 \\
\hline Balears, Illes & 0 & -5.973 & 11.924 & 17.876 & -1.196 & 1.119 & -6.183 & 0 & -7.373 & 18.123 & 27.182 & -4.119 & 40.778 & -6.856 \\
\hline Canarias & 4 & -4.697 & 7.356 & 11.033 & -1.781 & 1.593 & -0.081 & 1 & -5.572 & 10.355 & 15.525 & -1.380 & 2.267 & 1.574 \\
\hline Cantabria & 0 & -6.306 & 13.321 & 19.981 & -1.032 & 1.214 & -6.519 & 3 & -4.688 & 7.335 & 11.002 & -1.382 & 1.927 & 1.335 \\
\hline Castilla - La Mancha & 3 & -4.471 & 6.733 & 10.097 & -1.952 & 1.907 & -0.171 & 0 & -5.731 & 10.950 & 16.424 & -1.419 & 15.285 & -6.045 \\
\hline Castilla y León & 0 & -5.686 & 10.815 & 16.211 & -1.275 & 1.367 & -5.834 & 4 & -3.743 & 4.754 & 7.114 & -1.595 & 2.124 & 1.229 \\
\hline Cataluña & 1 & -6.619 & 14.714 & 22.048 & -1.849 & 1.956 & 0.459 & 0 & -9.106 & 28.711 & 42.655 & -1.451 & 10.835 & -7.647 \\
\hline Comunitat Valenciana & 1 & -5.918 & 11.689 & 17.534 & -2.065 & 2.139 & -0.100 & 0 & -7.529 & 19.072 & 28.597 & -1.050 & 8.688 & -6.890 \\
\hline Extremadura & 0 & -10.443 & 36.519 & 54.734 & -1.680 & 1.803 & -10.770 & 1 & -7.150 & 17.117 & 25.661 & -2.632 & 6.995 & 2.368 \\
\hline Galicia & 0 & -7.278 & 17.688 & 26.514 & -2.416 & 4.575 & -7.487 & 0 & -7.488 & 18.694 & 28.039 & -0.598 & 11.119 & -7.551 \\
\hline Madrid, Comunidad de & 0 & -6.926 & 16.041 & 24.060 & -1.040 & 0.635 & -7.161 & 1 & -5.585 & 10.416 & 15.612 & -1.917 & 3.388 & 1.637 \\
\hline Murcia, Región de & 2 & -3.631 & 4.454 & 6.677 & -2.315 & 2.724 & 0.025 & 0 & -7.777 & 20.171 & 30.248 & -0.945 & 11.685 & -7.412 \\
\hline Navarra, Comunidad Foral de & 2 & -4.253 & 6.045 & 9.066 & -1.334 & 0.906 & -0.052 & 0 & -9.479 & 30.048 & 45.031 & -1.049 & 11.299 & -8.506 \\
\hline País Vasco & 2 & -3.392 & 3.842 & 5.753 & -1.631 & 1.336 & -0.327 & 4 & -4.151 & 5.781 & 8.637 & -1.524 & 3.071 & 1.874 \\
\hline Rioja, La & 4 & -3.603 & 4.688 & 7.032 & -2.502 & 3.152 & -0.089 & 3 & -4.702 & 7.394 & 11.063 & -1.480 & 2.672 & 1.688 \\
\hline
\end{tabular}

Highlighted cells indicate a rejection of the null hypothesis at the 0.05 significance level. 
Table 2. 1 year ahead MAPE

First period

Estimation 1980-2001 / ex-post forecast 2002-2007

1 year ahead MAPE $\quad$ Naïve 1 Naïve 2 Autoregressive $\begin{gathered}\text { Fixed coefficients } \\ \text { Okun-Static Okun-Dynamic - }\end{gathered}$

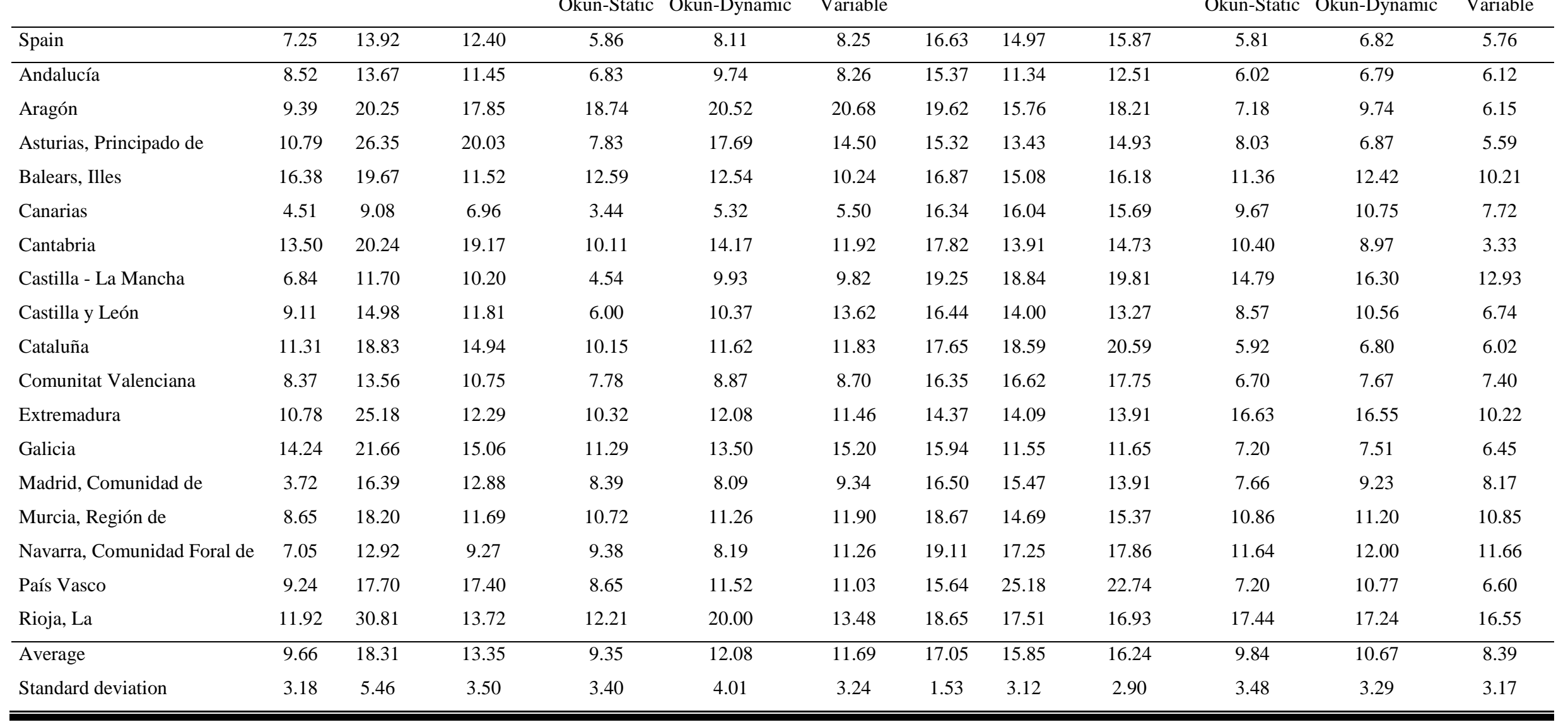

Second period

Estimation 1980-2007 / ex-post forecast 2008-2013

Fixed coefficients

Naïve 1 Naïve 2 Autoregressive $\begin{array}{cc}\text { Fixed coefficients } & \text { Okun - } \\ \text { Okun-Static Okun-Dynamic } & \text { Variable }\end{array}$

$5.81-6.82 \quad 5.76$

\begin{tabular}{|c|c|c|c|c|c|c|c|c|c|c|c|c|}
\hline Andalucía & 8.52 & 13.67 & 11.45 & 6.83 & 9.74 & 8.26 & 15.37 & 11.34 & 12.51 & 6.02 & 6.79 & 6.12 \\
\hline Aragón & 9.39 & 20.25 & 17.85 & 18.74 & 20.52 & 20.68 & 19.62 & 15.76 & 18.21 & 7.18 & 9.74 & 6.15 \\
\hline Asturias, Principado de & 10.79 & 26.35 & 20.03 & 7.83 & 17.69 & 14.50 & 15.32 & 13.43 & 14.93 & 8.03 & 6.87 & 5.59 \\
\hline Balears, Illes & 16.38 & 19.67 & 11.52 & 12.59 & 12.54 & 10.24 & 16.87 & 15.08 & 16.18 & 11.36 & 12.42 & 10.21 \\
\hline Canarias & 4.51 & 9.08 & 6.96 & 3.44 & 5.32 & 5.50 & 16.34 & 16.04 & 15.69 & 9.67 & 10.75 & 7.72 \\
\hline Cantabria & 13.50 & 20.24 & 19.17 & 10.11 & 14.17 & 11.92 & 17.82 & 13.91 & 14.73 & 10.40 & 8.97 & 3.33 \\
\hline Castilla - La Mancha & 6.84 & 11.70 & 10.20 & 4.54 & 9.93 & 9.82 & 19.25 & 18.84 & 19.81 & 14.79 & 16.30 & 12.93 \\
\hline Castilla y León & 9.11 & 14.98 & 11.81 & 6.00 & 10.37 & 13.62 & 16.44 & 14.00 & 13.27 & 8.57 & 10.56 & 6.74 \\
\hline Cataluña & 11.31 & 18.83 & 14.94 & 10.15 & 11.62 & 11.83 & 17.65 & 18.59 & 20.59 & 5.92 & 6.80 & 6.02 \\
\hline Comunitat Valenciana & 8.37 & 13.56 & 10.75 & 7.78 & 8.87 & 8.70 & 16.35 & 16.62 & 17.75 & 6.70 & 7.67 & 7.40 \\
\hline Extremadura & 10.78 & 25.18 & 12.29 & 10.32 & 12.08 & 11.46 & 14.37 & 14.09 & 13.91 & 16.63 & 16.55 & 10.22 \\
\hline Galicia & 14.24 & 21.66 & 15.06 & 11.29 & 13.50 & 15.20 & 15.94 & 11.55 & 11.65 & 7.20 & 7.51 & 6.45 \\
\hline Madrid, Comunidad de & 3.72 & 16.39 & 12.88 & 8.39 & 8.09 & 9.34 & 16.50 & 15.47 & 13.91 & 7.66 & 9.23 & 8.17 \\
\hline Murcia, Región de & 8.65 & 18.20 & 11.69 & 10.72 & 11.26 & 11.90 & 18.67 & 14.69 & 15.37 & 10.86 & 11.20 & 10.85 \\
\hline Navarra, Comunidad Foral de & 7.05 & 12.92 & 9.27 & 9.38 & 8.19 & 11.26 & 19.11 & 17.25 & 17.86 & 11.64 & 12.00 & 11.66 \\
\hline País Vasco & 9.24 & 17.70 & 17.40 & 8.65 & 11.52 & 11.03 & 15.64 & 25.18 & 22.74 & 7.20 & 10.77 & 6.60 \\
\hline Rioja, La & 11.92 & 30.81 & 13.72 & 12.21 & 20.00 & 13.48 & 18.65 & 17.51 & 16.93 & 17.44 & 17.24 & 16.55 \\
\hline Average & 9.66 & 18.31 & 13.35 & 9.35 & 12.08 & 11.69 & 17.05 & 15.85 & 16.24 & 9.84 & 10.67 & 8.39 \\
\hline Standard deviation & 3.18 & 5.46 & 3.50 & 3.40 & 4.01 & 3.24 & 1.53 & 3.12 & 2.90 & 3.48 & 3.29 & 3.17 \\
\hline
\end{tabular}


Table 3.2 years ahead MAPE

First period

Estimation 1980-2001 / ex-post forecast 2002-2007

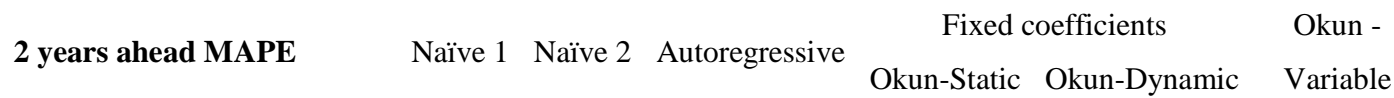

2 years ahead MAPE $\quad$ Naïve 1 Naïve 2 Autoregressive $\begin{gathered}\text { Fixed coefficients } \\ \text { Okun-Static Okun-Dynamic }\end{gathered}$ Variable

Spain

Andalucía

Aragón

Asturias, Principado de

Balears, Illes

Canarias

Cantabria

Castilla - La Mancha

Castilla y León

Cataluña

Comunitat Valenciana

Extremadura

Galicia

Madrid, Comunidad de

Murcia, Región de

Navarra, Comunidad Foral de

País Vasco

Rioja, La

Average

Standard deviation
$15.76 \quad 16.99$

$18.66 \quad 16.04$

$10.42 \quad 21.71$

$16.15 \quad 29.61$

$26.42 \quad 29.11$

$29.69 \quad 29.66$

$9.83 \quad 15.18$

$17.65 \quad 17.55$

$24.87 \quad 22.18$

$14.12 \quad 18.14$

$17.46 \quad 19.70$

$28.82 \quad 29.20$

$6.54 \quad 14.35$

$16.90 \quad 16.58$

$9.45 \quad 11.85$

$17.62 \quad 18.22$

$12.53 \quad 25.68$

$16.69 \quad 20.22$

$\begin{array}{ll}7.08 & 6.30\end{array}$
$6.61 \quad 9.03$

14.74
16.98

15.46

25.01

18.17

18.17
9.00

34.07

12.54

13.49

14.55

13.02

19.81

28.87

13.80

18.10

10.97

13.88

17.34

17.36

6.33

$8.68 \quad 11.11$

$\begin{array}{ll}14.53 & 15.73 \\ 25.23 & 23.32\end{array}$

$10.51 \quad 18.86$

20.52

18.86

24.28

5.42

23.20

7.27

12.73

19.72

9.97

14.85

22.28

14.46

15.33

17.51

7.35

14.42

\begin{tabular}{cc}
14.42 & 19.18 \\
\hline 15.02 & 16.80 \\
5.66 & 4.70 \\
\hline
\end{tabular}

5.66

\begin{tabular}{c}
7.59 \\
22.65 \\
13.01 \\
16.09 \\
19.85 \\
11.70 \\
17.50 \\
22.87 \\
12.93 \\
15.47 \\
12.76 \\
11.74 \\
19.18 \\
\hline 16.80 \\
4.70 \\
\hline
\end{tabular}

11.71
12.50
27.18

Estimation 1980-2007 / ex-post forecast 2008-2013

Naïve 1 Naïve 2 Autoregressive Fixed coefficients Okun -

\begin{tabular}{cccccc} 
& & & Okun-Static & Okun-Dynamic & Variable \\
\hline 30.34 & 14.71 & 18.51 & 9.42 & 11.57 & 9.35
\end{tabular}

$\begin{array}{llllll}34.84 & 14.44 & 21.97 & 12.20 & 13.14 & 9.65\end{array}$

$\begin{array}{lllllll}24.40 & 32.35 & 16.51 & 32.25 & 14.71 & 13.25 & 6.95\end{array}$

$\begin{array}{ccccccc}24.40 & 32.35 & 16.51 & 32.25 & 14.71 & 13.25 & 6.95 \\ 16.15 & 28.49 & 17.28 & 22.69 & 17.37 & 16.11 & 11.61\end{array}$

$\begin{array}{lllllll}8.88 & 27.23 & 16.80 & 21.32 & 13.85 & 13.10 & 9.53\end{array}$

$\begin{array}{lllllll}14.10 & 33.56 & 15.80 & 25.84 & 19.82 & 14.50 & 2.88\end{array}$

$\begin{array}{lllllll}13.79 & 34.28 & 17.61 & 22.00 & 21.88 & 17.52 & 12.78\end{array}$

$\begin{array}{ccccccc}13.79 & 34.28 & 17.61 & 22.00 & 21.88 & 17.52 & 12.78 \\ 20.10 & 29.58 & 14.32 & 18.66 & 13.10 & 14.25 & 7.80\end{array}$

$\begin{array}{lllllll}18.29 & 32.77 & 18.73 & 21.56 & 8.77 & 11.07 & 7.88\end{array}$

$\begin{array}{ccccccc}18.29 & 32.77 & 18.73 & 21.56 & 8.77 & 11.07 & 7.88 \\ 10.84 & 29.88 & 16.47 & 19.14 & 10.53 & 12.10 & 10.29\end{array}$

$\begin{array}{lllllll}10.84 & 29.88 & 16.47 & 19.14 & 10.53 & 12.10 & 10.29 \\ 10.00 & 28.91 & 12.21 & 26.87 & 33.02 & 34.22 & 10.08\end{array}$

$\begin{array}{lllllll}23.91 & 31.55 & 12.67 & 22.36 & 13.35 & 12.80 & 7.18\end{array}$

$\begin{array}{lllllll}20.46 & 29.54 & 14.93 & 21.31 & 12.43 & 15.50 & 12.16 \\ 16.04 & 31.64 & 15.38 & 21.38 & 14.96 & 15.36 & 12.68\end{array}$

$\begin{array}{lllllll}18.04 & 31.64 & 15.38 & 21.38 & 14.96 & 15.36 & 12.68 \\ 18.18 & 33.91 & 18.21 & 23.15 & 19.39 & 14.75 & 14.01\end{array}$

$\begin{array}{ccccccc}18.18 & 33.91 & 18.21 & 23.15 & 19.39 & 14.75 & 14.01 \\ 10.52 & 29.66 & 22.71 & 24.82 & 6.60 & 9.52 & 4.98\end{array}$

\begin{tabular}{ccccccc}
20.51 & 34.09 & 16.32 & 26.34 & 29.28 & 27.19 & 18.21 \\
\hline 16.81 & 31.17 & 16.04 & 22.81 & 15.87 & 15.60 & 9.76 \\
5.30 & 2.41 & 2.53 & 3.57 & 6.88 & 5.98 & 3.56 \\
\hline
\end{tabular}

3(4), 247-262, 2014 
Table 4. Results of the Diebold-Mariano test for 1 year ahead forecasts

\begin{tabular}{|c|c|c|c|c|c|c|c|c|}
\hline \multirow{4}{*}{1 year ahead } & \multicolumn{4}{|c|}{ First period } & \multicolumn{4}{|c|}{ Second period } \\
\hline & \multicolumn{4}{|c|}{ Estimation 1980-2001 / ex-post forecast 2002-2007 } & \multicolumn{4}{|c|}{ Estimation 1980-2007 / ex-post forecast 2008-2013 } \\
\hline & \multirow{2}{*}{ Best univariate model } & \multirow{2}{*}{ Best Okun-based model } & \multicolumn{2}{|c|}{ DM test } & \multirow{2}{*}{ Best univariate model } & \multirow{2}{*}{ Best Okun-based model } & \multicolumn{2}{|c|}{ DM test } \\
\hline & & & $\mathrm{S}(1)$ & $\mathrm{p}$-value & & & $\mathrm{S}(1)$ & $\mathrm{p}$-value \\
\hline Spain & Naïve 1 & Okun-Static & 0.93 & 0.35 & Naïve 2 & Okun - Variable & 2.31 & 0.02 \\
\hline Andalucía & Naïve 1 & Okun-Static & 0.91 & 0.36 & Naïve 2 & Okun-Static & 0.19 & 0.85 \\
\hline Aragón & Naïve 1 & Okun-Static & -2.97 & 0.00 & Naïve 2 & Okun - Variable & 2.04 & 0.04 \\
\hline Asturias, Principado de & Naïve 1 & Okun-Static & 1.74 & 0.08 & Naïve 2 & Okun - Variable & 1.92 & 0.06 \\
\hline Balears, Illes & Autoregressive & Okun - Variable & 0.28 & 0.78 & Naïve 2 & Okun - Variable & 0.35 & 0.73 \\
\hline Canarias & Naïve 1 & Okun-Static & 1.09 & 0.27 & Autoregressive & Okun - Variable & 1.90 & 0.06 \\
\hline Cantabria & Naïve 1 & Okun-Static & 2.40 & 0.02 & Naïve 2 & Okun - Variable & 2.30 & 0.02 \\
\hline Castilla - La Mancha & Naïve 1 & Okun-Static & 1.87 & 0.06 & Naïve 2 & Okun - Variable & 1.58 & 0.12 \\
\hline Castilla y León & Naïve 1 & Okun-Static & 1.32 & 0.19 & Autoregressive & Okun - Variable & 3.88 & 0.00 \\
\hline Cataluña & Naïve 1 & Okun-Static & 0.95 & 0.34 & Naïve 1 & Okun-Static & 1.66 & 0.10 \\
\hline Comunitat Valenciana & Naïve 1 & Okun-Static & 0.36 & 0.72 & Naïve 1 & Okun-Static & 1.55 & 0.12 \\
\hline Extremadura & Naïve 1 & Okun-Static & 0.53 & 0.60 & Autoregressive & Okun - Variable & 1.87 & 0.06 \\
\hline Galicia & Naïve 1 & Okun-Static & 1.32 & 0.19 & Naïve 2 & Okun - Variable & 1.70 & 0.09 \\
\hline Madrid, Comunidad de & Naïve 1 & Okun-Dynamic & -1.53 & 0.13 & Autoregressive & Okun-Static & 1.30 & 0.19 \\
\hline Murcia, Región de & Naïve 1 & Okun-Static & -0.70 & 0.48 & Naïve 2 & Okun - Variable & 1.05 & 0.29 \\
\hline Navarra, Comunidad Foral de & Naïve 1 & Okun-Dynamic & -0.35 & 0.73 & Naïve 2 & Okun-Static & 1.67 & 0.10 \\
\hline País Vasco & Naïve 1 & Okun-Static & 0.13 & 0.90 & Naïve 1 & Okun - Variable & 1.73 & 0.08 \\
\hline Rioja, La & Naïve 1 & Okun-Static & -0.33 & 0.74 & Autoregressive & Okun - Variable & 0.23 & 0.82 \\
\hline
\end{tabular}

Null Hypothesis: Forecast accuracy is equal. Alternative Hypothesis: Forecast accuracy is different. A negative value of S(1) indicates that the first method is better than the second while a positive value of S(1) indicates the opposite. Highlighted cells indicate a rejection of the null hypothesis at the 0.05 significance level. 
Table 5. Results of the Diebold-Mariano test for 2 years ahead forecasts

\begin{tabular}{|c|c|c|c|c|c|c|c|c|}
\hline \multirow{3}{*}{2 years ahead } & \multicolumn{4}{|c|}{ Estimation 1980-2001 / ex-post forecast 2002-2007 } & \multicolumn{4}{|c|}{$\begin{array}{c}\text { Second period } \\
\text { Estimation } 1980-2007 \text { / ex-post forecast 2008-2013 }\end{array}$} \\
\hline & & & & $M$ test & \multirow{2}{*}{ Best univariate model } & \multirow{2}{*}{ Best Okun-based model } & \multicolumn{2}{|c|}{ DM test } \\
\hline & Best univariate model & Best Ukun-based model & $\mathrm{S}(1)$ & $\mathrm{p}$-value & & & $S(1)$ & $\mathrm{p}$-value \\
\hline Spain & Autoregressive & Okun-Static & 2.17 & 0.03 & Naïve 2 & Okun - Variable & 0.79 & 0.43 \\
\hline Andalucía & Naïve 2 & Okun - Variable & 1.03 & 0.31 & Naïve 2 & Okun - Variable & 1.64 & 0.10 \\
\hline Aragón & Naïve 1 & Okun-Dynamic & -1.91 & 0.06 & Naïve 2 & Okun - Variable & 0.65 & 0.51 \\
\hline Asturias, Principado de & Naïve 1 & Okun-Static & 1.82 & 0.07 & Naïve 2 & Okun - Variable & 1.42 & 0.16 \\
\hline Balears, Illes & Autoregressive & Okun - Variable & 0.35 & 0.73 & Naïve 2 & Okun - Variable & 0.94 & 0.34 \\
\hline Canarias & Naïve 1 & Okun-Static & 1.73 & 0.08 & Naïve 2 & Okun - Variable & 1.30 & 0.20 \\
\hline Cantabria & Naïve 2 & Okun - Variable & 3.48 & 0.00 & Naïve 2 & Okun - Variable & 2.15 & 0.03 \\
\hline Castilla - La Mancha & Naïve 1 & Okun-Static & 1.68 & 0.09 & Naïve 2 & Okun - Variable & 1.03 & 0.30 \\
\hline Castilla y León & Autoregressive & Okun-Static & 0.19 & 0.85 & Naïve 2 & Okun - Variable & 1.99 & 0.05 \\
\hline Cataluña & Autoregressive & Okun - Variable & -0.99 & 0.32 & Naïve 2 & Okun - Variable & 1.30 & 0.19 \\
\hline Comunitat Valenciana & Autoregressive & Okun-Static & 1.03 & 0.30 & Naïve 2 & Okun - Variable & 1.01 & 0.31 \\
\hline Extremadura & Naïve 1 & Okun - Variable & 1.22 & 0.22 & Naïve 2 & Okun - Variable & 0.62 & 0.54 \\
\hline Galicia & Naïve 1 & Okun-Static & 1.58 & 0.11 & Naïve 2 & Okun - Variable & 0.98 & 0.00 \\
\hline Madrid, Comunidad de & Naïve 1 & Okun-Dynamic & -2.01 & 0.04 & Naïve 2 & Okun - Variable & 0.41 & 0.68 \\
\hline Murcia, Región de & Naïve 2 & Okun-Static & 0.40 & 0.69 & Naïve 2 & Okun - Variable & 0.57 & 0.57 \\
\hline Navarra, Comunidad Foral de & Naïve 1 & Okun-Dynamic & -0.64 & 0.52 & Naïve 2 & Okun - Variable & 1.09 & 0.28 \\
\hline País Vasco & Autoregressive & Okun-Static & 1.09 & 0.28 & Naïve 2 & Okun - Variable & 2.51 & 0.01 \\
\hline Rioja, La & Naïve 1 & Okun-Static & -0.68 & 0.50 & Naïve 2 & Okun - Variable & -0.39 & 0.69 \\
\hline
\end{tabular}

Null Hypothesis: Forecast accuracy is equal. Alternative Hypothesis: Forecast accuracy is different. A negative value of S(1) indicates that the first method is better than the second while a positive value of S(1) indicates the opposite. Highlighted cells indicate a rejection of the null hypothesis at the 0.05 significance level. 
Table 6. Results of the Panel Diebold-Mariano test

\begin{tabular}{lcccccc}
\hline \hline 1 year ahead - 1st period & Naïve 1 & Naïve 2 & AR & \multicolumn{2}{c}{ Okun (fixed) } & Okun \\
& & & & Static & Dynamic & (variable) \\
\hline \hline Naïve 1 vs. & & -5.70 & -3.35 & $\mathbf{1 . 7 5}$ & -2.45 & -2.37 \\
Naïve 2 vs. & 5.70 & & 7.66 & $\mathbf{6 . 5 6}$ & 7.31 & 5.39 \\
AR vs. & 3.35 & -7.66 & & $\mathbf{4 . 4 0}$ & 2.89 & 1.95 \\
Okun (fixed) - static vs. & $\mathbf{- 1 . 7 5}$ & $\mathbf{- 6 . 5 6}$ & $\mathbf{- 4 . 4 0}$ & & $\mathbf{- 3 . 7 9}$ & $\mathbf{- 5 . 4 4}$ \\
Okun (fixed) - dynamic vs. & 2.45 & -7.31 & -2.89 & $\mathbf{3 . 7 9}$ & & -0.45 \\
Okun (variable) vs. & 2.37 & -5.39 & -1.95 & $\mathbf{5 . 4 4}$ & 0.45 & \\
\hline \hline
\end{tabular}

\begin{tabular}{lcccccc}
\hline \hline 1 year ahead - 2nd period & Naïve 1 & Naïve 2 & AR & \multicolumn{2}{c}{ Okun (fixed) } & \multirow{2}{*}{ Okun } \\
& & & & Static & Dynamic & (variable) \\
\hline \hline Naïve 1 vs. & & 1.69 & 2.70 & $\mathbf{1 0 . 3 7}$ & 7.74 & $\mathbf{9 . 3 2}$ \\
Naïve 2 vs. & -1.69 & & -0.64 & $\mathbf{6 . 6 9}$ & 7.21 & $\mathbf{8 . 1 4}$ \\
AR vs. & -2.70 & 0.64 & & $\mathbf{8 . 1 0}$ & 6.86 & $\mathbf{9 . 3 0}$ \\
Okun (fixed) - static vs. & $\mathbf{- 1 0 . 3 7}$ & $\mathbf{- 6 . 6 9}$ & $\mathbf{- 8 . 1 0}$ & & $\mathbf{- 2 . 6 7}$ & 0.94 \\
Okun (fixed) - dynamic vs. & -7.74 & -7.21 & -6.86 & $\mathbf{2 . 6 7}$ & & $\mathbf{5 . 6 9}$ \\
Okun (variable) vs. & $\mathbf{- 9 . 3 2}$ & $\mathbf{- 8 . 1 4}$ & $\mathbf{- 9 . 3 0}$ & -0.94 & $\mathbf{- 5 . 6 9}$ & \\
\hline \hline
\end{tabular}

\begin{tabular}{lcccccc}
\hline \hline 2 years ahead - 1st period & Naïve 1 & Naïve 2 & AR & $\begin{array}{c}\text { Okun (fixed) } \\
\text { Static }\end{array}$ & $\begin{array}{c}\text { Okynamic } \\
\text { (variable) }\end{array}$ \\
\hline \hline Naïve 1 vs. & & $\mathbf{- 2 . 3 2}$ & -0.48 & 2.99 & -0.57 & -0.89 \\
Naïve 2 vs. & $\mathbf{2 . 3 2}$ & & $\mathbf{4 . 5 3}$ & $\mathbf{3 . 4 7}$ & $\mathbf{3 . 8 9}$ & $\mathbf{3 . 2 3}$ \\
AR vs. & 0.48 & $\mathbf{- 4 . 5 3}$ & & 1.14 & 1.59 & 1.74 \\
Okun (fixed) - static vs. & -2.99 & $\mathbf{- 3 . 4 7}$ & -1.14 & & -1.49 & -2.97 \\
Okun (fixed) - dynamic vs. & 0.57 & $\mathbf{- 3 . 8 9}$ & -1.59 & 1.49 & & 0.02 \\
Okun (variable) vs. & 0.89 & $\mathbf{- 3 . 2 3}$ & -1.74 & 2.97 & -0.02 & \\
\hline \hline
\end{tabular}

\begin{tabular}{lcccccc}
\hline \hline 2 years ahead - 2nd period & Naïve 1 & Naïve 2 & AR & \multicolumn{2}{c}{ Okun (fixed) } & Okun \\
& & & & Static & Dynamic & (variable) \\
\hline \hline Naïve 1 vs . & & 10.33 & 9.72 & 27.52 & 18.57 & $\mathbf{2 1 . 9 9}$ \\
Naïve 2 vs. & -10.33 & & -5.18 & 0.39 & 0.97 & $\mathbf{4 . 6 6}$ \\
AR vs. & -9.72 & 5.18 & & 6.00 & 7.60 & $\mathbf{1 0 . 2 5}$ \\
Okun (fixed) - static vs. & -27.52 & -0.39 & -6.00 & & -0.37 & $\mathbf{9 . 8 5}$ \\
Okun (fixed) - dynamic vs. & -18.57 & -0.97 & -7.60 & 0.37 & & $\mathbf{8 . 7 1}$ \\
Okun (variable) vs. & $\mathbf{- 2 1 . 9 9}$ & $\mathbf{- 4 . 6 6}$ & $\mathbf{- 1 0 . 2 5}$ & $\mathbf{- 9 . 8 5}$ & $\mathbf{- 8 . 7 1}$ & \\
\hline \hline
\end{tabular}

Null Hypothesis: Forecast accuracy is equal. Alternative Hypothesis: Forecast accuracy is different. A negative value of average $S(1)$ indicates that the method in the first column is better than the competing one while a positive value of average S(1) indicates the opposite. Highlighted cells indicate a rejection of the null hypothesis at the 0.05 significance level. 
where $\mathrm{S}_{\mathrm{i}}(1)$ is the value of the Diebold-Mariano statistic for region $\mathrm{i}$ and $\mathrm{N}$ is the total number of regions (17, in our case). The panel Diebold-Mariano test also has a standard normal limiting distribution. As we can see from table 6, the Okun model with fixed coefficient provides the best accuracy for 1 year ahead forecasts both in the first and the second period. In the second period, we cannot reject that the accuracy of the Okun model with time varying coefficient is also similar. This result does not hold, however, when we look at 2 years ahead forecasts. In this case, the best model for the first period is the naïve method assuming that growth rates are constant, but for the second period the Okun model with time varying coefficient is found to be the best. Although we cannot generalise, this evidence shows that this more flexible specification can be better suited for forecasting in the presence of structural change or recent changes in the business cycle dynamics.

\section{Concluding remarks}

The objective of the paper was to analyse the possibility of improving the forecasts for regional unemployment rates in Spain using a time-varying coefficient specification of the Okun's law. With this aim, we have carried out a forecasting competition in two time periods characterized by different macroeconomic conditions. The obtained results allow us to conclude that, in general, the consideration of models based on the Okun's law improve the forecasting performance in nearly all regions, particularly when the time-varying coefficient specification is used. However, the accuracy of the models is not good enough to provide reliable forecasts in real-time forecasting exercises for Spanish regions. Difficulties in order to obtain accurate forecasts of the Spanish aggregate unemployment rate have already been highlighted in the previous literature (see, for instance, Olmedo, 2011). Future research could expand into two directions: first, the consideration of non-linearities; and, second, the development of more sophisticated tools trying to better capture the complex relationship between unemployment, economic activity and other factors (i.e., macroeconometric forecasting models).

Acknowledgements. The authors gratefully acknowledge the comments and suggestions received from the editors and an anonymous referee. The usual disclaimer applies. Financial support is also acknowledged from the Spanish Ministry of Economy and Competitiveness through the project ECO2013-41022-R. A previous version of this article was presented at the "XL Reunion de Estudios Regionales - AECR”, Zaragoza, November 20th-21st 2014.

\section{References}

Adanu, K. (2005) A cross-province comparison of Okun's coefficient for Canada, Applied Economics, 37(5), 561-570.

Apergis, N. and Rezitis, A. (2003) An examination of Okun's law: evidence from regional areas in Greece, Applied Economics, 35(10), 1147-1151.

Ball, L., Jalles, J.T. and Loungani, P. (2015) Do forecasters believe in Okun's law? An assessment of unemployment and output forecasts, International Journal of Forecasting, 31(1), 176-184. 
Ballesteros Gallardo, J.A., Núñez Hernández, F. and Usabiaga Ibáñez, C. (2012) La Ley Okun para las regiones españolas: distintas aproximaciones econométricas, Instituto de Estadística y Cartografía de Andalucía, Documentos de Trabajo 4/2012.

Bernoth, K. and Pick, A. (2011) Forecasting the fragility of the banking and insurance sectors, Journal of Banking and Finance, 35(4), 807-818.

Chinn, M.D., Ferrara, L. and Mignon, V. (2013) Post-recession us employment through the lens of a non-linear Okun's law, National Bureau of Economic Research, Working Paper 19047.

Christopoulos, D.K. (2004) The relationship between output and unemployment: evidence from Greek regions, Papers in Regional Science, 83(3), 611-620.

Diebold, F.X. and Mariano, R. (1995) Comparing predictive accuracy, Journal of Business and Economic Statistics, 13(3), 253-263.

Durech, R., Minea, A., Mustea, L. and Slusna, L. (2014) Regional evidence on Okun's law in Czech Republic and Slovakia, Economic Modelling, 42, 57-65.

Dziechciarz, J. (1989) Changing and random coefficient models. A survey, in Hackl, P. (ed.) Seasonal analysis and forecasting of economic structural change, Springer Verlag, Berlin.

Elliott, G. and Timmermann, A. (2008) Economic forecasting, Journal of Economic Literature, 46(1), 3-56.

Engle, R.F. and Watson, M.W. (1987) The Kalman filter: applications to forecasting and rational-expectations models, in Bewley, T.F. (ed.) Advances in Econometrics: Fifth World Congress, Econometric Society Monograph, vol. 13, Cambridge University Press: Cambridge, 245-283.

Franses, P.H., Mcaleer, M. and Legerstee, R. (2014) Evaluating macroeconomic forecasts: a concise review of some recent developments, Journal of Economic Surveys, 28(2), 195208.

Franses, P. H., Paap, R. and Vroomen, B. (2004), Forecasting unemployment using an autoregression with censored latent effects parameters, (2004) International Journal of Forecasting, 20(2), 255-271.

Freeman, D.G. (2000) Regional tests of Okun's law, International Advances in Economic Research, 6(3), 557-570.

Funke, M. (1992) Time-series forecasting of the German unemployment rate, Journal of Forecasting, 11(2), 111-125.

Guisinger, A.Y. and Sinclair, T.M. (2015) Okun's Law in real time, International Journal of Forecasting, 31(1), 157-164.

Huang, H.C. and Yeh, C.C. (2013) Okun's Law in panels of countries and states, Applied Economics, 45(2), 191-199.

Kangasharju, A., Tavera C. and Nijkamp, P. (2012) Regional growth and unemployment: the validity of Okun's Law for the Finnish regions, Spatial Economic Analysis, 7(3), 381395.

Karfakis, C., Katrakilidis, C. and Tsanana, E. (2014) Does output predict unemployment? A look at Okun's Law in Greece, International Labour Review, 153 (3), 421-433.

Knotek, E. (2007), How useful is Okun's Law?, Federal Reserve Bank of Kansas City Economic Review, Fourth Quarter, 73-103.

Lopez-Bazo, E., del Barrio, T. and Artís, M. (2005) Geographical distribution of unemployment in Spain, Regional Studies, 39(3), 305-318.

Marie-Estelle, B. and Facchini, F. (2013) Okun's law in the French regions: a cross-regional comparison, Economics Bulletin, 33(1), 420-433.

Martín-Román, A. and Sylvina-Porras, M. (2012) La ley de Okun en España ¿por qué existen diferencias regionales?, paper presented at Reunion de Estudios Regionales, Bilbao. 
Min, C. and Zellner; A. (1993) Bayesian and non-bayesian methods for combining models and forecasts with applications to forecasting international growth rates, Journal of Econometrics, 56(1-2), 89-118.

Okun, A.M. (1962) Potential GNP: its measurement and significance, Proceedings of the Business and Economic Statistics Section, American Statistical Association, 98-104.

Olmedo, E. (2011) Is there chaos in the Spanish labour market?, Chaos, Solitons and Fractals, 44(12), 1045-1053.

Pereira, R.M. (2014) Okun's law, asymmetries and regional spillovers: evidence from Virginia metropolitan statistical areas and the District of Columbia, Annals of Regional Science, 52(2), 583-595.

Ramos, R., Clar, M. and Suriñach, J. (2000) Comparación de la capacidad predictiva de los modelos de coeficientes fijos frente a variables en los modelos econométricos regionales: un análisis para Cataluña, Estudios de Economía Aplicada, 15, 125-162.

Rothman, P. (1998) Forecasting asymmetric unemployment rates, Review of Economics and Statistics, 80(1), 164-168.

Shively, T. and Kohn, R. (1997) A Bayesian approach to model selection in stochastic coefficient regression models and structural time series models, Journal of Econometrics, 76(1-2), 39-52.

Villaverde, J. and Maza, A. (2007) Okun's law in the Spanish regions, Economics Bulletin, 18 (5), 1-11.

Villaverde, J. and Maza, A. (2009) The robustness of Okun's law in Spain, 1980-2004: regional evidence, Journal of Policy Modelling, 31(2), 289-297. 